\title{
Comparison of the Susceptibility of Two Hardwood Species, Mimosa scabrella Benth and Eucalyptus viminalis Labill, to Steam Explosion and Enzymatic Hydrolysis
}

\author{
L. P. Ramos*1, S. T. Carpes ${ }^{1,2}$, F. T. Silva ${ }^{3}$ and J. L. M. Ganter ${ }^{4}$ \\ ${ }^{1}$ Centro de Pesquisa em Química Aplicada, Departamento de Química, UFPR, C.P. 19.081, , 81531-990Curitiba, \\ PR, 81531-990; ${ }^{2}$ CEFET-Medianeira, C.P. 391, CEP: 85884-000, Medianeira, PR - Brazil; ${ }^{3}$ Departamento de \\ Biotecnologia, Faenquil, C.P. 116, CEP: 12600-000, Lorena, SP - Brazil; ${ }^{4}$ Departamento de Bioquímica, UFPR, \\ C.P. 19.046 , CEP: 81531-990, Curitiba - PR, Brazil
}

\begin{abstract}
Steam explosion of two hardwood species was carried out with and without addition of sulfuric acid $\left(\mathrm{H}_{2} \mathrm{SO}_{4} 0.5 \%\right.$, $p / v)$ as a pretreatment catalyst. In general, wood chips of Eucalyptus viminalis Labill were shown to be more amenable to pretreatment than chips derived from bolds of Mimosa scabrella Benth (bracatinga). This was apparent from all pretreatment parameters tested including the overall recovery yields of pretreated fractions, carbohydrates (pentoses and hexoses) recovered as water-solubles, yield of dehydration by-products and lignin susceptibility to acid hydrolysis. There was no evidence for complete deacetylation of both wood species during pretreatment and lignin appeared to undergo extensive acid hydrolysis at higher pretreatment severities. Steam treatment at $205^{\circ} \mathrm{C}$ for 5 min without addition of an acid catalyst was shown to be uncapable of removing the hemicellulose component from bracatinga chips, as determined by chemical analysis of the steam-treated water-insoluble fractions. Nearly $30 \%$ of the hemicellulose (xylan) found in bracating a remained unhydrolysed after pretreatment, whereas more than $90 \%$ of this component could be removed from eucalypt chips under the same pretreatment conditions. Likewise, pretreatment of eucalypt chips resulted in a more extensive solubilization of glucans (cellulose) by acid hydrolysis. Addition of dilute $\mathrm{H}_{2} \mathrm{SO}_{4}$ as a pretreatment catalyst generally increased the recovery yield of fermentable sugars in the water-soluble fractions and this effect was more pronounced for the pretreatment of bracatinga chips. Steamtreated substrates produced from bracatinga were also less accessible to enzymatic hydrolysis than those produced from eucalypt chips, regardless of the use of an acid catalyst.
\end{abstract}

Key words: Eucalyptus viminalis, Mimosa scabrella, steam explosion, pretreatment, bioconversion

\section{INTRODUCTION}

Lignocellulosic materials are inexhaustible resources that can be directly or indirectly used for the production of biomolecules and commodity chemicals. However, the industrial utilization of these renewable resources has been compromised by several factors such as the close association that exists among the three main components of the plant cell wall (cellulose, hemicellulose and lignin) and the low efficiency by which lignocellulosic substrates are converted through biological processes such as enzymatic hydrolysis and fermentation.

For many decades, stands of both Eucalyptus spp. and bracatinga (Mimosa scabrella Benth) have been largely exploited as reliable resources for a number of commercial applications ranging from heat-generating materials to renewable feedstocks for the chemical industry (Soares and Hosokawa, 1984; Suchek, 1991; Sturion, 1993). For instance, extensive plantations have been established in Brazil to fulfill their increasing demand by the charcoal and pulp and paper industries, among other activities. Production of essential oils from eucalypt leaves (Boland et al., 1991) as well as food additives (thickners and stabilizers) from bracatinga seeds (Ganter et al., 1992) have also been well characterized as potential applications for these fast growing trees.

The eucalypt plantations which now exist in Brazil are the largest in the world (Suchek, 1991) and bracatinga plantations are also expanding likewise (Soares and Hosokawa, 1984; Carpes, 1997). Depending of the regional climate and soil fertility, these trees can not only grow on rates of over $50 \mathrm{~m}^{3} /$ ha.year but also display the ability to

* Author for correspondence 
coppice from a recently cut stump. Therefore, considering the relatively large susteinability of reforestation programs based on these trees, there is a great opportunity for the utilization of their harvesting and processing residues as renewable sources for chemical feedstocks such as fermentable sugars, phenols, food additives, among others (Parisi, 1989; Vallander and Eriksson, 1990).

Several pretreatment options have been suggested in the literature to fractionate and effectively recover fermentable sugars from plant biomass (Parisi, 1989; Saddler et al., 1993). Among them, steam explosion has been indicated as one of the most effective pretreatment options to date. Several major advantages have been associated with steam explosion. They are: (a) the effective fractionation of wood into its three main components, cellulose, hemicellulose and lignin; (b) after steam treatment, theoretical yields of cellulose conversion can be achieved through enzymatic hydrolysis; (c) the steam-exploded lignin is still suitable for conversion to chemical products; (d) hemicellulose can be fully utilized and converted to liquid fuels; (e) fermentation inhibitors are readily extracted; (f) the method is effective for a wide variety of plant biomass, and (g) pretreatment conditions can be easily optimized to produce specific chemicals at high yield (Saddler et al., 1993). The major disadvantage is that, although steam explosion greatly enhances the enzymatic hydrolysis of hardwoods (Brownell and Saddler, 1984; Excoffier et al., 1991; Ramos et al., 1992a) and most agricultural residues (Dekker and Wallis, 1983; Kling et al., 1987; Tenrud et al., 1989; Deschamps et al., 1996) tested to date, it has not yet been fully developed for the use of softwoods (Ramos et al., 1992b). Furthermore, steam explosion produces a relatively low bulk density substrate which has to be first washed to remove inhibitors.

In this work, two hardwood species namely Mimosa scabrella Benth (bracatinga) and Eucalyptus viminalis Labill have been investigated as potential candidates for a bioconversion process based on steam explosion. Performance of these two species has been discussed in relation to recovery of hemicellulose sugars, chemical composition of both water-soluble and waterinsoluble fractions and susceptibility of the waterwashed cellulosic residue to enzymatic hydrolysis.

\section{MATERIALS AND METHODS}

Pretreatment: Air-dried wood chips (300-350 g, dry weight) with a typical moisture content of 10$15 \%(\mathrm{w} / \mathrm{w})$, derived from 7 to 10 year-old stems of E. viminalis and M. scabrella (Embrapa-Florestas, Colombo, PR, Brazil), were steam-treated with and without addition of an acid catalyst using a $0.65 \mathrm{~L}$ steam gun located at the Department of Biotechnology of Faenquil (Faculdade de Engenharia Química de Lorena, Lorena, SP, Brazil) (Silva, 1995). Pretreatment was always carried out in triplicates at a saturated steam temperature of $205^{\circ} \mathrm{C}$ for a fixed residence time of 5 min.

Acid impregnation was carried out by soaking the wood chips in $0.50 \%(\mathrm{w} / \mathrm{v}) \mathrm{H}_{2} \mathrm{SO}_{4}$ overnight at room temperature (RT). The excess of $\mathrm{H}_{2} \mathrm{SO}_{4}$ solution was discarded. Acid-impregnated chips were shown to have approximately $50 \%(\mathrm{w} / \mathrm{w})$ moisture content.

Bulk production of substrates for enzymatic hydrolysis (see below) was performed under similar pretreatment conditions using a $5 \mathrm{~L}$ steam gun located at the Pilot Plant Unit of the Federal University of Paraná (Curitiba, PR, Brazil) (Ramos et al., 1995). Pretreatment was carried out at $205^{\circ} \mathrm{C}$ for residence times ranging from 5 to 10 min, using untreated and acid-impregnated wood chips as described above. Similar pretreatment profiles were obtained when each of these highpressure steam vessels were utilized.

Steam pretreatment was performed by loading the chips directly into the steam gun. After treatment for a given temperature and residence time, the steam-treated material was released from the steam-gun by rapid despressurization, causing the material to expand (explode) into a collecting vessel (Ramos, 1992; Carpes, 1997). Substrates were then recovered by water washing. The resulting material was extracted twice with water at a $5 \%(\mathrm{w} / \mathrm{w})$ solids concentration. The waterinsoluble fraction was termed STE-WI and STBWI (water-insoluble fraction from steam-treated eucalypt and steam-treated bracatinga, respectively), whereas the water-soluble fraction or liquor was termed STE-WS and STB-WS (water-soluble fraction from steam-treated eucalypt and steam-treated bracatinga, respectively).

Chemical analysis of lignocellulosic materials before and after pretreatment: Total extractives were determined in both original, untreated wood 
chips ( $2 \mathrm{~g}$ of chips Wiley-milled to pass a 40 mesh screen) by a sequential treatments with ethanol:benzene $(1: 2, \mathrm{v} / \mathrm{v})$ and ethanol in a Soxhlet apparatus. The extracted material was then washed thoroughly with water, dried at $50-60^{\circ} \mathrm{C}$ and stored for further analysis.

Chemical analysis of substrates and raw materials were always performed in duplicates using a modification of the TAPPI Standard Method T222 os-74 for acid insoluble lignin (Klason lignin) (Dence, 1992). After swelling approximately $1 \mathrm{~g}$ of Wiley-milled fibers (40 mesh) in $15 \mathrm{~mL}$ of $72 \%$ $\mathrm{H}_{2} \mathrm{SO}_{4}(\mathrm{w} / \mathrm{w})$, distilled water was added until a $3 \%$ (w/w) acid concentration was reached and the suspension was treated for $70 \mathrm{~min}$ in an autoclave at $121^{\circ} \mathrm{C}$. Acid-insoluble lignin (Klason lignin) was measured gravimetrically and total carbohydrates were determined by HPLC (Irick $e t$ al., 1988). Acid-soluble lignin was determined in Klason lignin hydrolysates according to the Tappi Useful Method 250 (Dence, 1992).

Pentosan hydrolysis occurring during steam treatment was determined by HPLC analysis of the water-soluble (WS) fractions (see below) (Irick $e t$ al., 1988). Recovery yields of WS fractions were determined by evaporating an aliquot to dryness and expressing the amount in terms of $\mathrm{g} / 100 \mathrm{~g}$ of oven-dry wood.

The HPLC analysis of WS fractions and Klason hydrolysates was obtained with a Shimadzu HPLC system, model LC10AD, provided with a SIL10A autosampler and a RID10A refractive index detector. HPLC analysis was performed at $65^{\circ} \mathrm{C}$ in an Aminex HPX-87H column (Bio-Rad), eluted with $8 \mathrm{mM} \mathrm{H}_{2} \mathrm{SO}_{4}$ at a flow rate of $0.6 \mathrm{~mL} / \mathrm{min}$. Soluble sugars were quantified by calibration using cellobiose (retention time, RT of $7.2 \mathrm{~min}$ ), glucose (RT of $8.9 \mathrm{~min}$ ), xylose (RT of $9.6 \mathrm{~min}$ ), arabinose (RT of $10.4 \mathrm{~min}$ ) and acetic acid (RT of $14.7 \mathrm{~min}$ ) as external standards. Oligosaccharides (RT within 6.0 and $8.0 \mathrm{~min}$ ) were integrated collectively and expressed quantitatively as cellobiose.

Furfural and hydroxymethylfurfural (HMF) were also determined in each of the WS fraction by liquid chromatography using a Shimadzu HPLC system, model LC10AD, provided with a SPD10A variable wavelength UV/vis detector set at $276 \mathrm{~nm}$ (Silva, 1995). HPLC analyses were performed at $30^{\circ} \mathrm{C}$ in a LiChrospher $100 \mathrm{RP}-18(5 \mu \mathrm{m}$ particle size) column (Hewlett-Packard), eluted with acetonitrile/water 1:8 (v/v) containing $1 \%(\mathrm{p} / \mathrm{v})$ of acetic acid at a flow rate of $0.8 \mathrm{~mL} / \mathrm{min}$. Furfural and HMF were quantified by external calibration.

Lignin hydrolysis was assessed in the watersoluble (WS) fractions by ultraviolet (UV) spectroscopy using an HP 8452A diode-array UV spectrophotometer (Hewlett-Packard). After subtraction of the absorbance due to dehydration by-products determined chromatographycally, the specific absorbance at $276 \mathrm{~nm}$ was used to quantify the amount of lignin-derived phenolic compounds and water-soluble lignin-carbohydrate complexes that were produced as a result of pretreatment. An absortivity of $110 \mathrm{~L} / \mathrm{g} . \mathrm{cm}$ was used for the calculations (Dence, 1992).

Enzymatic hydrolysis of steam-treated fractions: Enzymatic hydrolysis was performed at $2 \%(\mathrm{w} / \mathrm{w})$ in a $50 \mathrm{mM}$ sodium acetate buffer, $\mathrm{pH}$ 4.8 , at $45^{\circ} \mathrm{C}$ and $145 \mathrm{rpm}$, using a mixture of Celluclast $1.5 \mathrm{~L}$ and Novozym 188 (Novo Nordisk) with an activity loading of approximately 35 FPU per gram of steam-treated substrate. An excess of Novozym 188 was used to prevent cellobiose accumulation (Chan et al., 1989). Enzymatic activities were determined according to Chan $e t$ al. (1989) and Ghose (1987). Glucose and cellobiose were analysed in substrate hydrolysates by HPLC and expressed in relation to the carbohydrate content (cellulose plus hemicellulose) of the pretreated material.

\section{RESULTS AND DISCUSSION}

Wood chips of both E. viminalis and M. scabrella were initially characterized with regard to their chemical composition. Although both the hardwood species had similar extractives and ash contents, their lignin and carbohydrate contents were slightly different, with the former having a lower cellulose content and higher lignin content than the latter (Table 1). Interestingly, both hardwood species were shown to have the same acetyl content and, based on their overall chemical composition, these species were not expected to present distinct susceptibilities to steam treatment. 
Table 1 - Chemical composition of E. viminalis and M. scabrella (bracatinga) wood chips.

\begin{tabular}{l|c|c}
\hline Component (\%) & E. viminalis & M. scabrella \\
\hline Glucan & $42.52(47.71)$ & $48.09(51.17)$ \\
Xylan & $15.15(17.00)$ & $16.50(17.55)$ \\
Arabinan & $1.19(1.33)$ & $1.18(1.26)$ \\
Acetyl groups & $0.77(0.86)$ & $0.76(0.81)$ \\
Klasonligrin & $25.70(28.83)$ & $23.50(25.00)$ \\
Extractives & $3.30(3.71)$ & $3.50(3.72)$ \\
Ash & $0.50(0.56)$ & $0.46(0.49)$ \\
\hline Total & $89.13(100)$ & $93.99(100)$ \\
\hline
\end{tabular}

Values in brackets represent the amount of each component after normalization.

Pretreatment of both wood species were initially carried out in a lab scale apparatus $(0.65 \mathrm{~L}$ steam gun) to ensure good process control and effective recovery of pretreatment fractions. At any of the conditions tested in this study, there was an excellent reproducibility of recovery yields for each of the water-soluble and water-insoluble fractions recovered after pretreatment (Table 2).

Pretreatment of wood chips without catalyst: In general, the overall recovery yield of pretreated fractions was lower when pretreatment was carried out in the absence of an acid catalyst (Table 2).

Pretreatment of bracatinga chips at $205^{\circ} \mathrm{C}$ for 5 min yielded only $78.57 \%$ in relation to the original wood dry weight, whereas $76.62 \%$ was recovered when eucalypt chips were pretreated under the same conditions. Compared to eucalypt, pretreatment of bracatinga yielded lower recovery of water-solubles and higher recovery of waterinsolubles, suggesting that hemicellulose removal by acid hydrolysis was considerably higher when pretreatment was carried out with eucalypt chips. This was confirmed by chemical analysis of the water-insoluble fibers, where STB-WI was shown to contain $7.56 \%$ of xylan while only $2.18 \%$ of xylan was found in the STE-WI fraction (Table 3).

Table 2 - Overall yield of fractions derived from steam explosion of E. viminalis and M. scabrella wood chips under both catalysed and non-catalysed conditions.

Water-solubles (WS) Water-insolubles (WI) Total

A. Steam-treated E. viminalis (STE)

Non-catalysed $\quad 13.74 \forall 0.18$

$62.88 \forall 1.79$

$76.62 \forall 1.96$

Catalysed

$29.61 \forall 0.57$

$70.01 \forall 0.57$

$99.62 \forall 0.66$

B. Steam-treated $M$. scabrella (STB)

\begin{tabular}{llll} 
Non-catalysed & $10.81 \forall 0.38$ & $67.76 \forall 0.94$ & $78.57 \forall 0.85$ \\
Catalysed & $27.14 \forall 0.32$ & $71.73 \forall 0.43$ & $98.87 \forall 0.75$ \\
\hline
\end{tabular}


Table 3 - Chemical composition of water-insoluble fractions derived from steam-exploded E. vitaminalis and M. scabrella under both catalysed and non-catalysed conditons.

\begin{tabular}{|c|c|c|c|c|}
\hline \multirow[t]{2}{*}{ Component (\%) } & \multicolumn{2}{|c|}{ STE-WI } & \multicolumn{2}{|c|}{ STB-WI } \\
\hline & Non-catalysed & Catalysed & Non-catalysed & Catalysed \\
\hline Glucan & 65.99 & 68.23 & 55.21 & 58.91 \\
\hline Xylan & 2. 18 & 1. 19 & 7.56 & 1.95 \\
\hline Arabinan & nd & nd & nd & nd \\
\hline Acetyl groups & 0.35 & 0.41 & 0.45 & 0.31 \\
\hline $\mathrm{K} 1$ as on lignin & 30.47 & 30.58 & 35.31 & 37.16 \\
\hline Ash & 0.48 & 0.45 & 0.41 & 0.53 \\
\hline Total & 99.47 & 100.86 & 98.94 & 98.86 \\
\hline
\end{tabular}

To characterize the susceptibility of these two hardwood species by steam explosion, the WS fraction derived from each of their pretreatment runs was further investigated by HPLC. Indeed, there was a larger amount of oligosaccharides and a correspondingly lower amount of xylose in the STB-WS fraction (bracatinga), compared to the STE-WS fraction (Table 4). Glucose was also present in eucalypt hydrolysates (STE-WS) in higher yields, as well as phenolic compounds derived from lignin hydrolysis (acid-soluble lignin and/or water-soluble lignin-carbohydrate complexes). Therefore, at the conditions tested in the absence of an added catalyst $\left(205^{\circ} \mathrm{C}, 5 \mathrm{~min}\right)$, eucalypt chips were more effectively pretreated than bracatinga chips, regardless of their relatively equivalent chemical composition (see Table 1).

Table 4 - Recovery yield obtained in water-soluble fractions derived from steam-exploded E. vitaminalis and M. scabrella under both catalysed and non-catalysed conditions.

\begin{tabular}{lcccccc}
\hline Component $(\%)^{*}$ & \multicolumn{2}{c}{ STE-WS } & & \multicolumn{2}{c}{ STB-WS } \\
\cline { 2 - 3 } \cline { 6 - 7 } & Non-catalysed & Catalysed & & Non-catalysed & Catalysed \\
\hline Oligosaccharides & $2.16(3.07)$ & $1.42(2.01)$ & & $8.67(11.95)$ & $1.62(2.21)$ \\
Glucose & $2.41(5.67)$ & $4.29(10.09)$ & & $1.56(3.24)$ & $1.95(4.05)$ \\
Xylose & $4.85(32.06)$ & $10.86(71.80)$ & & $3.11(18.87)$ & $8.80(53.33)$ \\
Arabinose & $0.68(57.05)$ & $0.43(35.93)$ & & $0.79(66.97)$ & $0.84(71.17)$ \\
Acetic acid & $0.66(86.26)$ & $0.32(42.05)$ & & $0.50(65.78)$ & $0.38(50.59)$ \\
Acid-soluble lignin & $3.53(11.95)$ & $3.66(12.40)$ & & $1.62(5.92)$ & $2.71(9.88)$ \\
Furfural & $0.72(4.36)$ & $0.99(6.00)$ & & $0.08(0.48)$ & $0.58(3.52)$ \\
Hydroxymethylfurfural & $0.19(0.40)$ & $0.51(1.06)$ & & $0.02(0.04)$ & $0.22(0.46)$ \\
\hline Total & 15.34 & 22.62 & & 16.56 & 17.25
\end{tabular}

* Expressed in relation to the original wood dry weight; values in brackets represent the recovery yield of each component in relation to their precursors in Table 1. 
A

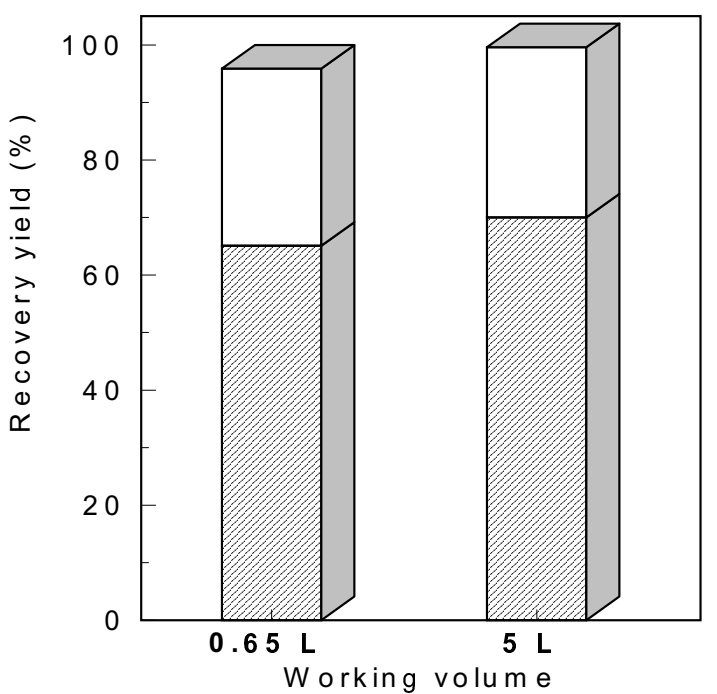

B

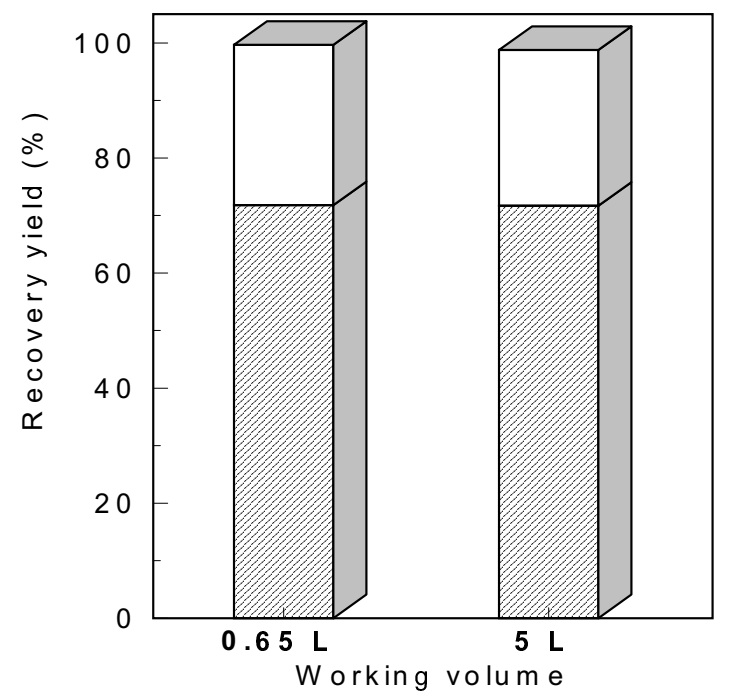

Figure 1 - Effect of scaling-up on the recovery yields of both water-soluble (WS) and water-insoluble (WI) fractions derived from steam-treated (A) E. viminalis and (B) M. scabrella chips. Pretreatment was performed in high-pressure steam vessels with distinct working volumes $(0.65$ and $5 \mathrm{~L})$ at $205^{\circ} \mathrm{C}$ for 5 min using acidimpregnated wood chips. Open bars, WS fraction; dashed bars, WI fraction.

Pretreatment of bracatinga chips at lower severities, that is, in the absence of an added catalyst, resulted in accumulation of a relatively large amount of oligosaccharides in the watersoluble fractions. For this reason, each watersoluble fraction derived from bracatinga was posthydrolysed with sulfuric acid in order to render all carbohydrates in their monomeric form. This way, the oligosaccharides present in STB-WS fraction were shown to be almost completely composed of xylan oligomers (data not shown).

The efficiency of steam explosion as a pretreatment method is primarily based on hydrolytic reactions involving lignin and hemicelluloses (Tanahashi, 1990). However, a number of side reactions may compromise pretreatment efficiency by yielding less accessible substrates for enzymatic hydrolysis or by causing accumulation of inhibitory compounds to either enzymes or fermentation microorganisms (Palmqvist et al., 1996). Among them, dehydration of monosaccharides yielding furfural (from pentoses such as xylose and arabinose) and hydroxymethylfurfural (from hexoses such as glucose) has been indicated as one of the main side reactions during high-pressure steaming and its occurrence may be directly related to pretreatment severity. Indeed, the occurrence of both furfural and hydroxymethylfurfural in STEWS hydrolysates (eucalypt) was nearly 10 times higher than the levels found in STB-WS hydrolysates (bracatinga). Hence, E. viminalis was more permeable to the penetrating steam than bracatinga (higher porosity) and pretreatment had an extensive hydrolytic effect on its xylan component (autohydrolysis).

Pretreatment of both wood species in the absence of an acid catalyst did not result in complete deacetylation of the hemicellulose component originally found within the wood chips. In addition, arabinose was the monosaccharide recovered in highest yield (see values in brackets in Table 4). On the other hand, there was a very low accumulation of water-soluble dehydration by-products as a result of pretreatment (furfural and hydroxymethylfurfural), indicating that hydrolytic reactions largely predominated over degradation reactions such as dehydration. However, these volatile compounds could not be quantitatively recovered as water-solubles because they were partially lost to the atmosphere after explosive decompression.

The lignin component of bracatinga chips 
appeared to be less amenable to steam treatment than the lignin component found in eucalypt chips. Nearly $12 \%$ of eucalypt lignin was hydrolysed as a result of pretreatment, yielding monomers (mostly phenols) and lignin-carbohydrate complexes that were responsible for a considerable increase in the UV light absorbance of the water-solubles at 276 $\mathrm{nm}$ (aromatic water-soluble chromophores). In contrast, lignin hydrolysis contributed to only $1.62 \%$ weight loss of bracatinga chips after pretreatment, which corresponded to a $5.92 \%$ weight loss of the lignin component found within the wood chips. However, in both cases, there might have been an over-estimation of lignin hydrolysis because the amount of UV light absorbed could be partly attributed to watersoluble wood extractives.

It is also important to realize that the total recovery yields shown in Table 4 have resulted from an extensive investigation of the water-solubles (WS) using liquid chromatography (HPLC), whereas those figures shown in Table 2 have been determined gravimetrically by evaporating an aliquot of the water-solubles to dryness and expressing it in relation to the oven-dry wood weight. Therefore, values of WS recovery in Tables 2 and 4 must not be cross-examined without considering that (a) volatiles have been partially lost by evaporation while generating the data shown in Table 2 and (b) data shown in Table 4 are restricted to water-soluble compounds that were both qualitatively and quantitatively determined by HPLC.

Pretreatment of wood chips after impregnation with an acid catalyst: In general, addition of sulfuric acid as a pretreatment catalyst increased the recovery yield of fermentable sugars in the water-soluble fractions and this effect was more pronounced for the pretreatment of bracatinga chips.

The overall recovery yields were radically increased from 78.57 to $98.87 \%$ and from 76.62 to $99.62 \%$ in both pretreatment runs using bracatinga and eucalypt chips, respectively. This substantial increase in the overall yield was readily attributed to the much higher recovery of fermentable sugars in the water-soluble fractions, largely due to the greater stability of pentoses at lower $\mathrm{pH}$ (Springer and Harris, 1982). The recovery yield of STB-WS and STE-WS respectively increased from 10.81 to $27.14 \%$ and from 13.74 to $29.61 \%$ as a result of the added catalyst (Table 2).

Acid catalysis had a considerable effect on the chemical composition of water-insoluble fractions. Due to a more extensive hydrolysis of wood polysaccharides, the hemicellulose content of WI fractions was considerably reduced (Table 3). For instance, the xylan content of STB-WI was reduced to only $1.95 \%$, compared to the $7.56 \%$ residual xylan found in the STB-WI derived from non-catalysed pretreatment conditions. Consequently, there was an increase in both lignin and glucan contents of the WI fractions.

Compared to the non-catalysed pretreatment runs, higher glucose yields were also detected in both WS fractions, indicating a more extensive solubilization of the cellulose component. In the presence of sulfuric acid at $205^{\circ} \mathrm{C}$ for $5 \mathrm{~min}$, up to $4 \%$ of the cellulose component found in bracatinga chips was hydrolysed, whereas pretreatment of eucalypt chips under the same conditions resulted in nearly $10 \%$ cellulose solubilization (Table 4 ). In the presence of an added catalyst, most of the soluble sugars found in the WS fractions were in their monomeric form and xylose accounted for the vast majority of all sugars detected. The highest xylose recovery, accounting for $70 \%$ of the xylan found within the wood chips, was obtained from pretreatment of acid-impregnated eucalypt chips. This was nearly $40 \%$ higher than the xylose recovered from bracatinga chips under similar pretreatment conditions.

Acid catalysis also triggered faster dehydration rates of pentoses and hexoses in the WS fractions. However, as mentioned before, the figures shown in Table 4 are likely underestimated as there was no attempt to recover quantitatively all of the volatiles produced during pretreatment. Nevertheless, as a result of the added catalyst, the concentration of furfural increased in the STB-WS by a factor of 7.25, whereas a much lower increase was observed for the STE-WS fraction. The concentration of hydroxymethylfurfural in the WS fractions followed a similar pattern. 
Among other observations detracted from Table 4: (a) there was an indication that arabinose was partially degraded at the highest pretreatment severity using acid-impregnated eucalypt chips, particularly if the complete absence of this monosaccharide is recalled from the chemical analysis of the resulting steam-treated substrate (Table 3) and (b) the addition of sulfuric acid as an acid catalyst reduced the recovery yield of acetic acid in the water-soluble fractions.

There was no evidence for a direct effect of the added catalyst on hydrolysis of eucalypt lignin, as detracted from the literally identical amount of acid-soluble lignin in both STE-WS fractions. On the other hand, the recovery yield of acid-soluble lignin from bracatinga chips increased from $6 \%$ to nearly $10 \%$ after addition of an acid catalyst. This is an additional evidence for the lower susceptibility of bracatinga lignin to pretreatment and acid hydrolysis, probably due to a relatively lower content of acid-labile aryl-ether linkages within its chemical structure (Tanahashi, 1990), as compared to the lignin component found in eucalypt chips.

Susceptibility of steam-treated materials to enzymatic hydrolysis: Bulk production of substrates for enzymatic hydrolysis was performed in a $5 \mathrm{~L}$ steam gun at three pretreatment conditions: (a) $205^{\circ} \mathrm{C}$ for 10 min using untreated wood chips and $205^{\circ} \mathrm{C}$ for (b) $5 \mathrm{~min}$ and (c) 10 min using acid-impregnated chips as described earlier. These were chosen to allow for a direct comparison among substrates produced at a given pretreatment condition $\left(205^{\circ} \mathrm{C}\right.$ for 5 min using acid-impregnated chips) and to assess the effect of longer residence times (higher pretreatment severities) on the susceptibility of acidimpregnated wood chips to enzymatic hydrolysis. Even though similar pretreatment profiles were obtained in both high-pressure steam vessels (Figure 1), closer mass balances were obtained when pretreatment was carried out at the smaller reactor, probably due to a better reproducibility of pretreatment parameters, less heterogeneity and easier recovery of pretreated materials from the collecting vessel.

The chemical composition of bulk substrates prepared for hydrolysis is shown in Table 5. In general, pretreated substrates derived from eucalypt were free of any residual hemicellulose, whereas all steam-treated substrates derived from bracatinga still contained an appreciable amount of xylan in their chemical composition. In addition, the cellulose content of steam-treated bracatinga was generally lower than that of steam-treated eucalypt, whereas the lignin content was generally higher, except for the substrate derived from pretreatment of acid-impregnated wood chips at $205^{\circ} \mathrm{C}$ for $10 \mathrm{~min}$

Table 5 - Chemical composition of steam-treated substrates prepared for enzimatic hydrolysis using the 5L steam-gun.

\begin{tabular}{lcccc}
\hline Pretreatment conditions $^{*}$ & Glucan & Xylan & Lignin & Total \\
\hline A. E. viminalis (STE-WT) & & & & \\
$205^{\circ} \mathrm{C}, 10 \mathrm{~min}$ & 68.4 & nd & 32.7 & 101.1 \\
$205^{\circ} \mathrm{C}, 5 \mathrm{~min}, 0.5 \% \mathrm{H}_{2} \mathrm{SO}_{4}$ & 68.2 & nd & 32.3 & 100.5 \\
$205^{\circ} \mathrm{C}, 10 \mathrm{~min}, 0.5 \% \mathrm{H}_{2} \mathrm{SO}_{4}$ & 63.9 & nd & 36.6 & 100.5 \\
B. M. scabrella (STB-WT) & & & & \\
$205^{\circ} \mathrm{C}, 10 \mathrm{~min}$ & 61.1 & 4.5 & 36.2 & 101.8 \\
$205^{\circ} \mathrm{C}, 5 \mathrm{~min}, 0.5 \% \mathrm{H}{ }_{2} \mathrm{SO}_{4}$ & 60.0 & 4.5 & 36.5 & 101.0 \\
$205^{\circ} \mathrm{C}, 10 \mathrm{~min}, 0.5 \% \mathrm{H}_{2} \mathrm{SO}_{4}$ & 59.9 & 5.6 & 34.8 & 100.3 \\
\hline
\end{tabular}



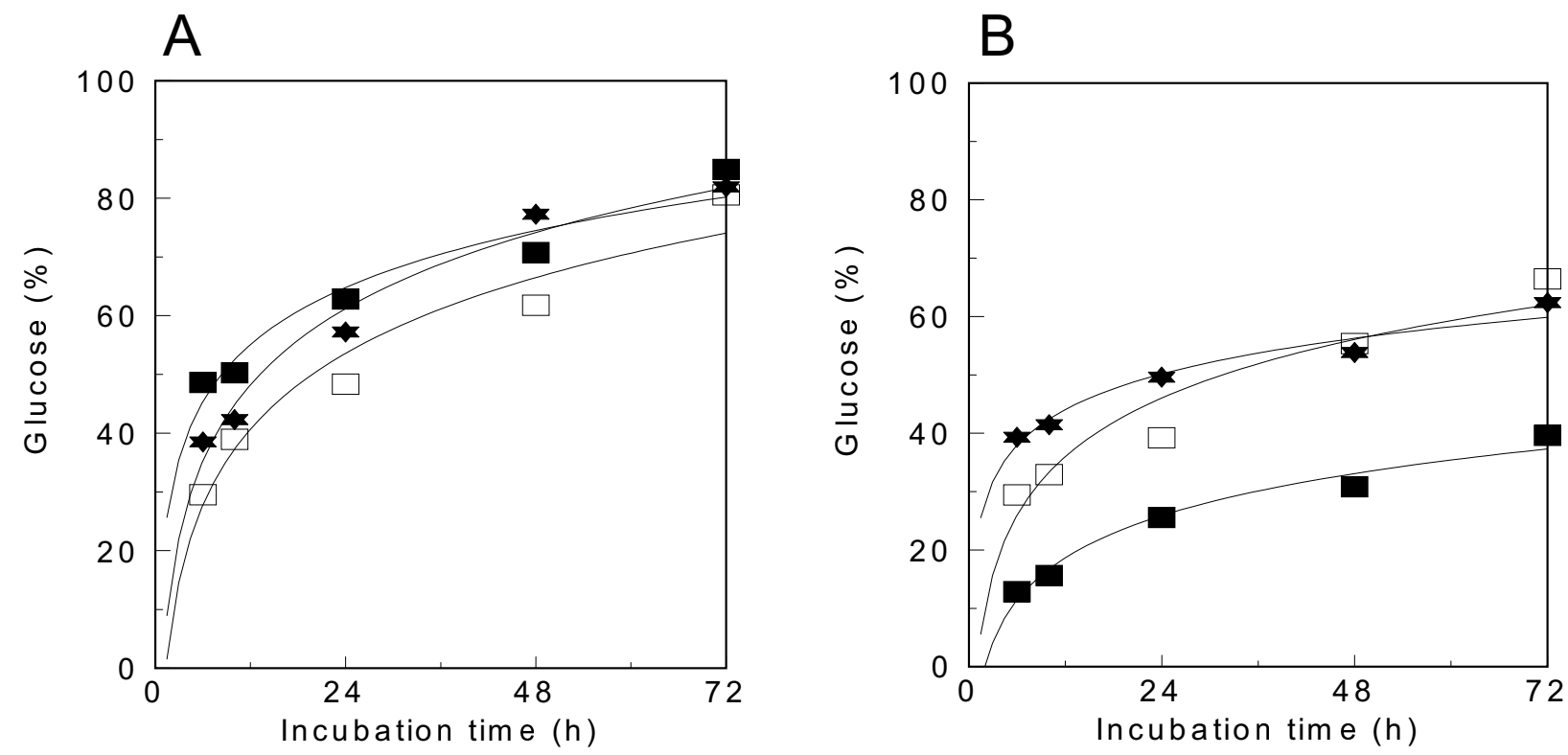

Figure 2 - Glucose yields obtained from the enzymatic hydrolysis of water-insoluble fractions derived from steamexploded (A) E. viminalis (STE-WI) and (B) M. scabrella (STB-WI). Pretreatment was carried out at ( $205^{\circ} \mathrm{C}$ for $10 \mathrm{~min}$ (non-catalysed conditions) and at $205^{\circ} \mathrm{C}$ for $(\sim) 5$ and $(\vee) 10 \mathrm{~min}$ after impregnation of the wood chips with dilute sulfuric acid (catalysed conditions).

Steam-treated substrates derived from eucalypt chips (STE-WI fractions) were more amenable to enzymatic hydrolysis than substrates derived from bracatinga chips (STB-WI fractions), supporting the previous hypothesis that E. viminalis pretreats more easily than M. scabrella. For pretreatment runs realized under non-catalysed conditions, nearly $80 \%$ of the cellulose component found in the STE-WI fraction (eucalypt) was saccharified when hydrolysis was carried out with 35 FPU per gram of cellulose for $72 \mathrm{~h}$ at $2 \%(\mathrm{w} / \mathrm{w})$ (Figure $2 \mathrm{~A})$. In contrast, for substrates produced from bracatinga chips under the same conditions, only $40 \%$ of the cellulose component could be hydrolysed by the concerted action of the enzymes (Figure 2B).

Likewise, acid-catalysed steam-treated substrates derived from eucalypt chips (STE-WI fractions) were more amenable to enzymatic hydrolysis than those derived from bracatinga chips (STB-WI fractions) (Figure 2). However, under the same hydrolysis conditions, all the substrates produced from acid-impregnated eucalypt were shown to be as accessible for hydrolysis as those produced under non-catalysed pretreatment conditions, suggesting that acid catalysis added little to the substrate accessibility of steam-treated eucalypt. In contrast, steam-treated substrates produced from acid-impregnated bracatinga were shown to be more accessible to hydrolysis than those produced from non-impregnated wood chips (non-catalysed pretreatment conditions) (Figure 2B), even though yields higher that $60 \%$ could not be achieved.

\section{CONCLUSIONS}

Chips of Mimosa scabrella Benth (bracatinga) were shown to be not as amenable to steam treatment as those derived from logs of Eucalyptus viminalis Labill. This was apparent from all pretreatment parameters tested including the overall recovery yields of water-soluble and waterinsoluble fractions, glucose and xylose recovery in the water-solubles, yield of dehydration byproducts and lignin susceptibility to acid hydrolysis. In general, addition of dilute $\mathrm{H}_{2} \mathrm{SO}_{4}$ as an acid catalyst generally increased the recovery yield of fermentable sugars in the water-soluble fractions and this effect was more pronounced for the pretreatment of bracatinga chips. Steamtreated substrates produced from eucalypt were also more accessible to hydrolysis than those produced from bracatinga under both catalysed and non-catalysed pretreatment conditions. However, acid catalysis did not result in any apparent increase in substrate accessibility of 
steam-treated eucalypt. Based on the chemical composition and performance of both wood species during pretreatment, it seemed that fractionation of bracatinga required more drastic pretreatment conditions than eucalypt because the former was less permeable to the penetrating steam than the latter and contained a lignincarbohydrate component that was considerably less-susceptible to acid hydrolysis.

\section{RESUMO}

Duas espécies de angiospermas foram comparadas em relação à suas susceptibilidades ao prétratamento por explosão a vapor. De um modo geral, cavacos industriais de Eucalyptus viminalis Labill apresentaram-se mais susceptíveis ao prétratamento a vapor do que cavacos derivados de Mimosa scabrella Benth (bracatinga). Tal observação foi baseada em quatro parâmetros de avaliação: rendimento da fração insolúvel em água (fração fibrosa); recuperação de carboidratos na fração aquosa; quantidade liberada de produtos de desidratação de açúcares na fração aquosa; e despolimerização parcial da lignina por hidrólise ácida. $\mathrm{O}$ pré-tratamento a $205^{\circ} \mathrm{C}$ por $5 \mathrm{~min}$, na ausência de um catalisador ácido, demonstrou ser insuficiente para a hidrólise e solubilização das hemiceluloses presentes na bracatinga. Aproximadamente $30 \%$ das xilanas de bracatinga prevalesceram após o pré-tratamento nestas condições, enquanto que cerca de $90 \%$ das xilanas de eucalipto foram removidas sob os mesmos padrões de severidade. Da mesma forma, o prétratamento de eucalipto resultou em maiores graus de solubilização de glucanas (celulose) a partir dos cavacos, indicando que este tipo de madeira é mais susceptível ao pré-tratamento do que cavacos derivados de bracatinga. A adição de ácido sulfúrico diluído como catalisador do processo aumentou o rendimento de açúcares solúveis na fração aquosa e este efeito foi mais pronunciado no pré-tratamento de cavacos de bracatinga. Finalmente, o componente celulósico dos substratos derivados de bracatinga também apresentou-se menos susceptível à hidrólise enzimática do que aquele presente em substratos pré-tratados a vapor derivados de eucalipto e tal comportamento foi observado independentemente do uso de ácido sulfúrico como catalisador da reação.
Acknowledgements. The authors are grateful to the "Conselho Nacional de Desenvolvimento Científico e Tecnológico" (CNPq, Brazil) for the financial support to carry out this study (PADCT II, grant QEQ 62.0194/95.2). The technical support of Dr. André Ribeiro Cotrim, Melissa Umata and Cristine Rodrigues is also greatly acknowledged.

\section{REFERENCES}

Boland, D. J.; Brophy, J. J. \& House, A. P. N. (eds.), Eucalyptus Leaf Oils - Use, Chemistry, Distillation and Marketing. Sydney, Inkata, 1991. 252 p.

Brownell, H. H. \& Saddler, J. N. (1984), Steam-explosion pretreatment for enzymatic hydrolysis. Biotechnol. Bioeng. Symp., 14, 55-68

Carpes, S. T. (1997), Pré-tratamento a vapor de Mimosa scabrella (bracatinga) visando a recuperação dos hidrolisados hemicelulósicos. M.Sc. Thesis, Universidade Federal do Paraná, Curitiba, Paraná, Brazil. 121 p.

Chan, M.; Breuil, C.; Schwald, W. \& Saddler, J. N. (1989), Comparison of methods for quantifying the hydrolytic potential of cellulase enzymes. Appl. Microbiol. Technol., 31, 413-418

Dekker, R. F. H. \& Wallis, A. F. A. (1983), Enzymic saccharification of sugarcane bagasse pretrated by autohydrolysis- steam explosion. Biotechnol. Bioeng., 25, 3027-3048

Dence, C. W. (1992), The determination of lignin. In: Methods in Lignin Chemistry, eds. S. Y. Lin \& C. W. Dence. New York, Springer-Verlag, 1992. pp. 33-62

Deschamps, F. C.; Ramos, L. P. \& Fontana, J. D. (1996), Pretreatment of sugarcane bagasse for enhanced ruminal digestion. Appl. Biochem. Biotechnol., 57/58, 171-182

Excoffier, G.; Toussaint, B. \& Vignon, M. R. (1991), Saccharification of steam-exploded poplar wood. Biotechnol. Bioeng., 38, 1308-1317

Ganter, J. L. M.; Milas, M.; Corrêa, J. B. C.; Reicher, F. \& Rinaudo, M. (1992), Study of solution properties of galactomannan from the seeds of Mimosa scabrella. Carbohydr. Polymers, 17, 171-175

Ghose, T. K. (1987), Measurement of cellulase activities. Pure and Appl.Chem., 59, 257-268

Irick, T. J.; West, K.; Brownell, H. H.; Schwald, W. \& Saddler, J. N. (1988), Comparison of colorimetric and HPLC techniques for quantitating the carbohydrate components of steam-treated wood. Appl. Biochem. Biotechnol., 17/18, 137-149

Kling, S. H.; Carvalho Neto, C.; Ferrara, M. A.; Torres, J. C. R.; Magalhães, D. B. \& Ryu, D. D. Y. (1987), Enhancement of enzymatic hydrolysis of sugar cane bagasse by steam explosion pretreatment. Biotechnol. Bioeng., 29, 1035-1039 
Palmqvist, E.; Hahn-Hägerdal, B.; Galbe, M. \& Zacchi, G. (1996), The effect of water-soluble inhibitors from steam-pretreated willow on enzymatic hydrolysis and ethanol fermentation. Enz. Microb. Technol., 19, 470476

Parisi, F. (1989), Advances in lignocellulosics hydrolysis and in the utilization of the hydrolysates. In: Advances in Biochemical Engineering and Biotechnology, vol. 38, ed. A. Fiechter. Springer-Verlag, Berlin, pp. 53-87

Ramos, L. P. (1992), Steam treatment and enzymatic hydrolysis of Eucalytptus viminalis Labill. Ph.D. Thesis, University of Ottawa, Ontario, Canada. 224 p.

Ramos, L. P.; Breuil, C.; Kushner, D. N. \& Saddler, J. N. (1992a), Steam pretreatment conditions for effective enzymatic hydrolysis and recovery yields of Eucalyptus viminalis wood chips. Holzforschung, 46, 149-154

Ramos, L. P.; Breuil, C. \& Saddler, J. N. (1992b), Comparison of steam pretreatment of eucalyptus, aspen and spruce wood chips and their enzymatic hydrolysis. Appl. Biochem. Biotechnol., 34/35, 37-47

Ramos, L. P.; Mathias, A. L.; Fontana, J. D. \& Almeida, N. H. (1995), Development of a small pilot plant for pretreating lignocellulosic materials. Paper presented at the Fourth Brazilian Symposium on the Chemistry of Lignins and Other Wood Components, November 28 - December 01, Recife, PE, Brazil

Saddler, J. N.; Ramos, L. P. \& Breuil, C. (1993), Steam pretreatment of lignocellulosic residues. In: Bioconversion of Forest and Agricultural Plant Wastes, ed. Saddler, J. N.. C. A. B. International, London, pp. 73-92

Silva, F. T. (1995), Obtenção de insumos químicos a partir do aproveitamento integral do bagaço de cana. Ph.D. Thesis, Universidade Estadual de Campinas, Campinas, São Paulo. 106 p.
Soares, R. V. \& Hosokawa, R. T. (1984), Estimativa da biomassa energética de árvores de bracatinga (Mimosa scabrella Benth). Boletim Técnico IBDE, 8 , 38-47

Springer, E. L. \& Harris, J. F. (1982), Prehydrolysis of aspenwood with water and with dilute aqueous sulfuric acid. Svensk. Papperstidn., 85, 152-154

Sturion, J. A. (1993), Variação genética de características de crescimento e de qualidade de madeira em progênies de Eucalyptus viminalis Labill. Ph.D. Thesis, Universidade Federal do Paraná, Curitiba, PR. 112 p

Suchek, V. I. (1991), The role of the planted forest in the pulp and paper industry in Brazil. The Forestry Chronicle, 67, 636-648

Tanahashi, M. (1990), Characterization and degradation mechanisms of wood components by steam explosion and utilization of exploded wood. Wood Res., 77, 49117

Tenrud, I. E.; Theander, O.; Torneport, L. \& Vallander, L. (1989), Changes in chemical composition of steam-exploded wheat straw during enzymic hydrolysis. Enzyme Microb. Technol., 11, 500-506

Vallander, L. \& Eriksson K.-E. (1990), Production of ethanol from lignocellulosic materials: state of the art. In: Advances Biochemical Engineering and Biotechnology, vol. 42, ed. A. Fiechter. SpringerVerlag, Berlin, pp. 63-95
Received: January 15, 1999 Revised: February 12, 1999; Accepted: September 22, 1999. 